\title{
ВПЛИВ МЕЛАТОНІНУ НА СТАН ОКСИДАНТНОЇ ТА АНТИОКСИДАНТНОЇ СИСТЕМ I РІВЕНЬ ГІДРОГЕН СУЛЬФІДУ В КРОВІ ЩУРІВ ЗА УМОВ ЕКСПЕРИМЕНТАЛЬНОЇ НЕФРОПАТІЇ
}

Вступ. Окиснювальний стрес залучений у патогенез різноманітних захворювань, включаючи гостре і хронічне ушкодження нирок, та характеризується підвищенням внутрішньоклітинного рівня активних фрорм оксигену. Це відіграє важливу роль у розвитку нефропатії та є потенційною ціллю для терапевтичного втручання. В останні роки актуальне також вивчення ролі $\mathrm{H}_{2} \mathrm{~S}$ у підтриманні окисно-відновного гомеостазу та впливу на активність антиоксидантного захисту. Одним із найбільш поширених антиоксидантів є мелатонін. Він здатний перехоплювати вільні радикали та стимулювати активність антиоксидантних ензимів. Однак залишаються нез'ясованими механізми його впливу на вміст $\mathrm{H}_{2} \mathrm{~S}$ та антиоксидантну систему крові при нефропатії.

Мета дослідження - 3'ясувати вплив мелатоніну на стан біохімічних показників, оксидантної та антиоксидантної систем і рівень гідроген сульфріду в крові щурів за умов експериментальної нефрропатії.

Методи дослідження. Експеримент проведено на 127 нелінійних щурах-самцях масою 0,16-0,18 ке. Експериментальну нефропатію моделювали шляхом одноразового внутрішньочеревного введення фролієвої кислоти в дозі 250 мг/кг маси тіла. Мелатонін вводили інтрагастрально впродовж 3 та 7 днів після моделювання нефропатії в дозі 10 мг/ке. У плазмі крові визначали вміст сечовини, креатиніну, ТБК-активних продуктів, карбонільних похідних протеїнів нейтрального $\left(О \mathrm{M}_{370}\right)$ та основного $\left(О \mathrm{M}_{430}\right)$ характеру, церулоплазміну, $\mathrm{SH}$-груп і $\mathrm{H}_{2} \mathrm{~S}$, у гемолізаті еритроцитів - активність каталази, супероксиддисмутази (SOD), глутатіонпероксидази (GPX) та глутатіон-S-трансорерази (GST).

Результати й обговорення. За умов нефропатії у крові щурів спостерігали підвищення концентрації сечовини, креатиніну, вмісту ТБК-активних продуктів, ОМБ ${ }_{370}$, ОМБ $_{430}$, церулоплазміну та зниження активності антиоксидантних ензимів, таких, як каталаза, SOD, GPx, GST, а також вмісту SH-груп і $\mathrm{H}_{2} \mathrm{~S}$. Ці зміни свідчили про порушення функціонального стану нирок, розвиток окиснювального стресу та виснаження антиоксидантного захисту. Введення мелатоніну впродовж 7 днів сприяло нормалізації показників, що характеризували фрункціональний стан нирок, оксидантний стан крові, та мало позитивний вплив на активність каталази, GPX, GST, рівень церулоплазміну, вміст SH-груп і $\mathrm{H}_{2} \mathrm{~S}$.

Висновок. Введення екзогенного мелатоніну в дозі 10 мг/кг упродовж 3 і 7 днів знижує прояви нефротичного синдрому та вільнорадикального окиснення біомолекул, а також має нормалізуючий вплив на антиоксидантну систему і вміст $\mathrm{H}_{2} \mathrm{~S}$, що, ймовірно, зумовлено його здатністю нейтралізувати вільні радикали та активувати антиоксидантні ензими.

КЛЮЧОВІ СЛОВА: нефропатія; фолієва кислота; антиоксидантна система; мелатонін; гідроген сульфід.

ВСТУП. Окиснювальний стрес залучений у патогенез різноманітних захворювань, включаючи гостре і хронічне ушкодження нирок, а також гіпертонічну та діабетичну нефропатії [1, 2]. Він характеризується підвищенням внутрішньоклітинного рівня активних фрорм оксигену (АФО), що відіграє важливу роль в ушкодженні нирок та $€$ потенційною ціллю для терапевтичного втручання.

Низькі рівні АФО необхідні для передачі сигналів, проліферації, росту й енергетичного метаболізму клітин. Надмірна їх кількість здат() І. О. Коляник, І. В. Геруш, Н.П.Григор'єва, 2021. на призводити до запалення, ушкодження та, в кінцевому результаті, загибелі клітин [2]. Оскільки АФО можуть реагувати $з$ ліпідами, протеїнами та ДНК, вони є токсичними молекулами, що спричиняють окиснювальне ушкодження клітин.

Еритроцити володіють потужнішою антиоксидантною системою, ніж інші клітини організму, оскільки їх фрункціональна роль пов'язана 3 транспортуванням оксигену з легень до тканин. У процесі транспортування еритроцити піддаються впливу АФО, що значно ушкоджують їх структуру та порушують фрункціональну здатність 
[3]. Антиоксидантна система еритроцитів представлена як неензимними низькомолекулярними антиоксидантами, зокрема глутатіоном та аскорбіновою кислотою, так і ензимними антиоксидантами, що включають супероксиддисмутазу (SOD), каталазу, глутатіонпероксидазу (GPx), глутатіон-S-транссеразу (GST) [4].

В останні роки активно вивчають роль гідроген сульсріду в підтриманні окисно-відновного гомеостазу. $\mathrm{H}_{2} \mathrm{~S}$ захищає клітини від окиснювального стресу, діючи як прямий поглинач вільних радикалів або ж активуючи систему антиоксидантного захисту [5]. Він відновлює цистин до цистеїну, цим самим підвищуючи рівень внутрішньоклітинного глутатіону - основного антиоксиданта в клітинному захисті від окиснювального стресу [6].

Надмірна кількість АФО викликає окиснювальне ушкодження клітинних структур через дисбаланс в оксидантно-антиоксидантній рівновазі. Саме тому доцільним $€$ застосування 3 терапевтичною метою антиоксидантних засобів, що сприятиме відновленню балансу між продукуванням та виведенням АФО. Одним із найбільш поширених антиоксидантів є мелатонін, що відомий як активний перехоплювач вільних радикалів. Окрім того, він стимулює синтез антиоксидантних ензимів та активує синтез глутатіону [7].

Мета дослідження - з'ясувати вплив мелатоніну на стан біохімічних показників, оксидантної та антиоксидантної систем і рівень гідроген сульфріду в крові щурів за умов експериментальної несрропатії.

МЕТОДИ ДОСЛІДЖЕННЯ. Експеримент проводили на 127 білих статевозрілих щурах-самцях масою 0,16-0,18 кг. Усі маніпуляції з експериментальними тваринами виконували з дотриманням основних положень Закону України “Про захист тварин від жорстокого поводження" (2006), Директиви Ради Європи 2010/63 EU щодо експериментів на тваринах.

Моделювали нефропатію шляхом одноразового внутрішньочеревного введення фолієвої кислоти ("Sigma-Aldrich", США) в дозі 250 мг/кг маси тіла [8]. Тварин поділили на 5 груп: 1-ша контрольна; 2-га - експериментальні тварини із змодельованою нефропатією, 3-й день; 3-тя щури, яким на тлі моделювання експериментальної недрропатії щоденно внутрішньошлунково впродовж 3 днів вводили мелатонін ("Sigma-Aldrich", США) в дозі 10 мг/кг маси тіла; 4-та - тварини із змодельованою нефропатією, 7-й день; 5-та - щури з експериментальною нефропатією, яким щоденно протягом 7 днів вводили мелатонін у дозі 10 мг/кг маси тіла.
У плазмі крові визначали вміст сечовини (ензимним уреазним методом, використовуючи реактиви ПрАТ "Реагент", Україна); креатиніну [9]; ТБК-активних продуктів [10]; карбонільних похідних протеїнів нейтрального $\left(O \mathrm{O}_{370}\right)$ та основного $\left(\mathrm{OMП}_{430}\right)$ характеру [11]; церулоплазміну [12]; $\mathrm{SH}-г р у п ~[13] ; ~ \mathrm{H}_{2} \mathrm{~S}$ [14]. У гемолізаті еритроцитів визначали активність супероксиддисмутази [15]; каталази [16]; глутатіонпероксидази [17, 18]; глутатіон-S-трансфрерази [19]. Вимірювання проводили на спектрофотометрі "Agilent Cary 60".

Варіаційно-статистичне опрацювання отриманих результатів здійснювали з використанням програмного пакета для персональних комп'ютерів Microsoft Excel за допомогою непараметричного критерію Вілкоксона. Усі дані пред-

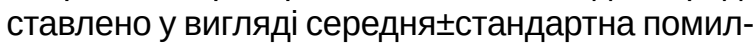
ка середньої $(\mathrm{M} \pm \mathrm{m})$. Результати вважали достовірними при $p \leq 0,05$.

РЕЗУЛЬТАТИ Й ОБГОВОРЕННЯ. ДЛЯ ОЦінКИ функціонального стану нирок визначали концентрацію креатиніну та сечовини в плазмі крові щурів за умов експериментальної нефрропатії.

Встановлено зростання концентрації креатиніну (рис. 1) та сечовини (рис. 2) на 140,5 і 26,6 \% відповідно на 3-й день та на 30,7 і 14,6 \% відповідно на 7-й день експерименту порівняно з контрольною групою тварин. Введення екзогенного мелатоніну впродовж 3 днів знижувало концентрацію креатиніну на $19 \%$, але вона все ще достовірно перевищувала рівень показників контрольної групи щурів майже у 2 рази. Застосування мелатоніну протягом 7 днів зменшувало

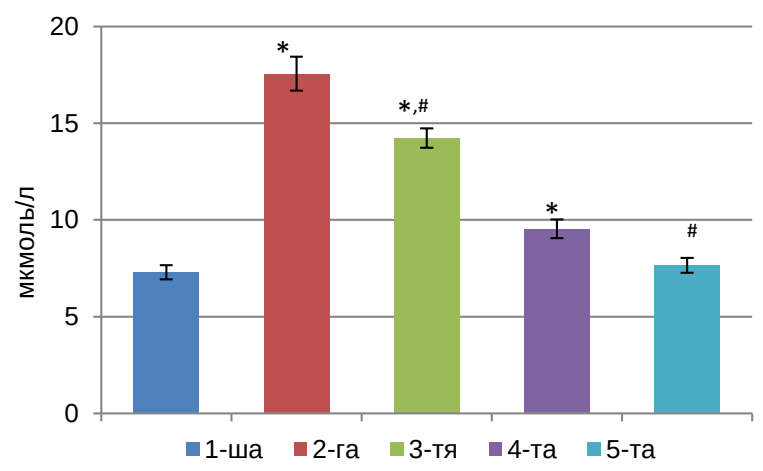

Рис. 1. Вміст креатиніну в плазмі крові щурів за умов нефропатії та введення мелатоніну.

Примітки:

1. 1-ша - контрольна; 2-га - нефропатія, 3-й день; 3-тя - нефропатія+мелатонін, 3-й день; 4-та - нефропатія, 7-й день; 5-та - нефропатія+мелатонін, 7-й день; дані представлено у вигляді середня стандартна помилка

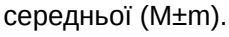

2. * - статистично значущі відмінності порівняно 3 показниками контрольної групи тварин $($ <<0,05); \# - статистично значущі відмінності порівняно з показниками щурів із несропатією $(p<0,05)$. 


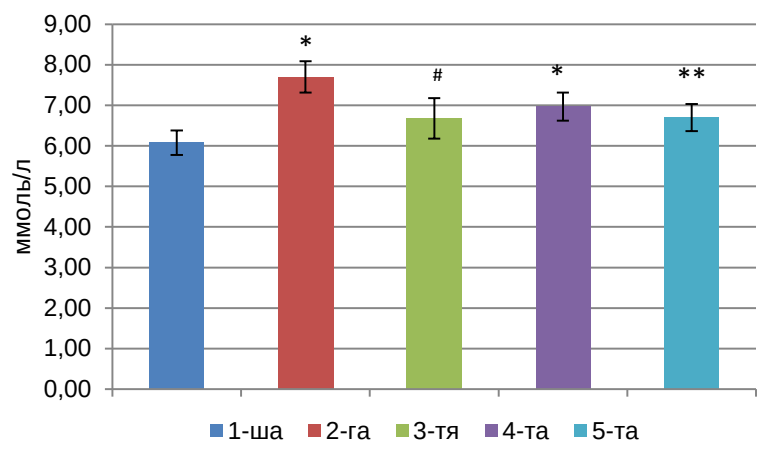

Рис. 2. Вміст сечовини в плазмі крові щурів за умов нефропатії та введення мелатоніну.

Примітки:

1. 1-ша - контрольна; 2-га - нефропатія, 3-й день; 3-тя - нефропатія+мелатонін, 3-й день; 4-та - нефропатія, 7-й день; 5-та - нефропатія+мелатонін, 7-й день; дані представлено у вигляді середняєстандартна помилка середньої $(\mathrm{M} \pm \mathrm{m})$

2. * - статистично значущі відмінності порівняно 3 показниками контрольної групи тварин $(p<0,05)$; \# - статистично значущі відмінності порівняно з показниками щурів із несропатією $(\mathrm{p}<0,05)$; ** - статистично значущі відмінност порівняно з показниками контрольної групи тварин $(p<0,01)$

його рівень на 19,2 \%, і він досягав значень контрольної групи тварин. На 3-й день експерименту за умов використання мелатоніну концентрація сечовини знижувалася на 13,2 \%.

Креатинін та сечовина $€$ кінцевими продуктами азотистого обміну, що відображають одну з найважливіших функцій нирок-азотовидільну, порушення якої спостерігають при токсичному ураженні нирок. Значне підвищення рівня креатиніну та сечовини в плазмі крові свідчить про погіршення фрільтраційної функції нирок, поси- лення пасивної реабсорбції в ниркових канальцях і порушення здатності нирок виводити 3 кровотоку продукти азотистого метаболізму. Використання мелатоніну знижує ці показники, що $є$ результатом покращення фрільтраційної здатності нирок щодо виведення ними продуктів азотистого обміну.

Однією з причин зазначених порушень фрільтраційної фрункції нирок $€$ посилення процесів вільнорадикального окиснення біополімерів у нирках. Ступінь вільнорадикального ушкодження оцінювали за вмістом ТБК-активних продуктів і карбонільних похідних протеїнів нейтрального та основного характеру в плазмі крові щурів. Встановлено (табл.) підвищення вмісту ТБК-активних продуктів як на 3-й, так і на 7-й дні нефропатії на 32,8 та 20,8 \% відповідно порівняно 3 контрольною групою тварин. Вміст ОМП $\mathrm{OMП}_{430}$ збільшувався на 57,8 і 19,4 \% відповідно на 3-й день нефропатії порівняно з показниками контрольної групи щурів.

У щурів з експериментальною нефропатією на 7-й день зростав вміст карбонільних похідних протеїнів нейтрального (на 53,1 \%) та основного (на 50,0 \%) характеру порівняно з контрольною групою тварин. Підвищення досліджуваних показників свідчило про посилення процесів вільнорадикального окиснення за умов виникнення нефрропатії.

Вільнорадикальне окиснення призводить до зміни структурних і фрункціональних властивостей мембран та активності ензимів, що є несприятливою умовою для фрункціонування органів і систем [20].

Таблиця - Вплив мелатоніну на показники оксидантної та антиоксидантної систем і рівень гідроген сульфріду в крові щурів за умов експериментальної нефропатії

\begin{tabular}{|c|c|c|c|c|c|}
\hline Показник & $\begin{array}{l}\text { Контроль } \\
(\mathrm{n}=36)\end{array}$ & $\begin{array}{c}\text { Нефрропатія, } \\
\text { 3-й день }(n=25)\end{array}$ & $\begin{array}{c}\text { Недропатія+ } \\
\text { мелатонін, } \\
\text { 3-й день }(n=25)\end{array}$ & $\begin{array}{c}\text { Неорропатія, } \\
\text { 7-й день }(n=24)\end{array}$ & $\begin{array}{l}\text { Неоропатія+ } \\
\text { мелатонін, } \\
\text { 7-й день }(n=24)\end{array}$ \\
\hline $\begin{array}{l}\text { ТБК-активні } \\
\text { продукти, мкмоль/л }\end{array}$ & $4,66 \pm 0,23$ & $6,19 \pm 0,43^{\text {** }}$ & $5,30 \pm 0,42$ & $5,63 \pm 0,18^{* *}$ & $4,30 \pm 0,23^{\# \#}$ \\
\hline $\begin{array}{l}\text { ОМП }_{\text {зтої, мкмоль/г }} \\
\text { протеїну }\end{array}$ & $0,64 \pm 0,02$ & $1,01 \pm 0,03^{* *}$ & $0,81 \pm 0,03^{* *, \# \#}$ & $0,98 \pm 0,05^{* *}$ & $0,71 \pm 0,02^{* *, \# \#}$ \\
\hline $\begin{array}{l}\text { ОМП }_{430}, \text { мкмоль/г } \\
\text { протеїну }\end{array}$ & $0,36 \pm 0,01$ & $0,43 \pm 0,02^{* *}$ & $0,32 \pm 0,01^{\# \#}$ & $0,54 \pm 0,04^{* *}$ & $0,51 \pm 0,04^{* *}$ \\
\hline SOD, Од/мг Hb & $1,90 \pm 0,04$ & $1,65 \pm 0,08^{*}$ & $1,87 \pm 0,09$ & $1,74 \pm 0,03^{*}$ & $1,75 \pm 0,05^{\star}$ \\
\hline Каталаза, кмоль/хв/л & $13,16 \pm 0,34$ & $10,50 \pm 0,30^{* *}$ & $12,35 \pm 0,26^{\# \#}$ & $10,13 \pm 0,47^{\star \star}$ & $11,54 \pm 0,55^{* *, \#}$ \\
\hline GPх, нмоль/хв/мг Нb & $6,91 \pm 0,37$ & $2,02 \pm 0,34^{* \star}$ & $4,11 \pm 0,37^{* *, \# \#}$ & $2,40 \pm 0,28^{* *}$ & $4,79 \pm 0,29^{\star \star,}, \# \#$ \\
\hline GST, нмоль/хв/мг Нb & $53,04 \pm 2,19$ & $50,37 \pm 2,39$ & $50,97 \pm 2,08$ & $47,32 \pm 1,58^{*}$ & $53,10 \pm 2,08^{\#}$ \\
\hline Церулоплазмін, мг/л & $180,5 \pm 5,7$ & $254,3 \pm 13,7^{* *}$ & $216,7 \pm 12,6^{* *, \#}$ & $314,0 \pm 23,0^{\star \star}$ & $206,2 \pm 15,7^{\# \#}$ \\
\hline SН-групи, мкмоль/л & $2,49 \pm 0,06$ & $1,83 \pm 0,11^{* *}$ & $2,32 \pm 0,13^{\# \#}$ & $2,26 \pm 0,16^{* *}$ & $2,40 \pm 0,11$ \\
\hline $\mathrm{H}_{2} \mathrm{~S}, \mathrm{kмоль/л}$ & $75,71 \pm 0,84$ & $53,90 \pm 1,14^{\star \star}$ & $68,27 \pm 1,81^{* *, \# \#}$ & $57,30 \pm 2,05^{\star *}$ & $65,29 \pm 1,96^{* *, \#}$ \\
\hline
\end{tabular}

Примітки:

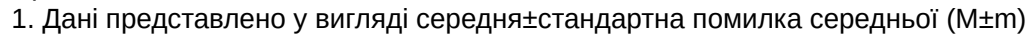

2. * - статистично значущі відмінності порівняно з показниками контрольної групи тварин; \# - статистично значущі відмінності порівняно з показниками групи щурів із несропатією ( $<<0,05)$; ** -статистично значущі відмінності порівняно з показниками контрольної групи тварин; - статистично значущі відмінності порівняно 3 показниками групи щурів із нефропатією на 7-й день експерименту ( $<<0,01)$. 
Введення мелатоніну призводило до зниження вмісту ТБК-активних продуктів на 23,6 \% на 7-й день експерименту, і він досягав рівня контрольної групи тварин. Вміст ОМБ ${ }_{370}$ та ОМБ після введення мелатоніну зменшувався на 19,8 і 25,6 \% відповідно на 3-й день виникнення нефропатії порівняно з показниками щурів із нефропатією. Введення мелатоніну протягом 7 днів викликало зниження рівня ОМБ 370 на 27,6 \%, але їх вміст усе ще достовірно відрізнявся від показників контрольної групи тварин.

Експериментальна несропатія спричиняла порушення і в системі антиоксидантного захисту.

Так, активність SOD знижувалась як на 3-й, так і на 7-й дні на 13,2 та 8,4% відповідно порівняно $з$ контрольною групою тварин. Результати нашого дослідження продемонстрували зменшення на 3-й та 7-й дні експерименту активності каталази на 20,2 і 23,0 \% відповідно порівняно 3 контрольною групою щурів.

Обидва вищезазначені ензими перетворюють активні форми оксигену в більш стабільні молекули шляхом складного каскаду реакцій і відіграють ключову роль у захисті клітин від окиснювального ушкодження та підтриманні клітинного окисно-відновного гомеостазу [21].

Встановлено зміни активності ензимів глутатіонової системи. Спостерігали зниження активності GPх на 70,8 \% на 3-й день та на 65,3 \% на 7-й день експерименту. На 7-й день відзначали зменшення активності GST на 10,8 \% порівняно зі значеннями контрольної групи тварин.

Глутатіонпероксидаза - Se-вмісний ензим, фрункція якого полягає у перетворенні пероксидів та ОН•у нетоксичні речовини шляхом окиснення відновленого глутатіону до дисульфіду глутатіону [1]. Вона синтезується переважно в нирках, тому визначення активності GPх у крові є прогностичним маркером захворювання нирок. Глутатіон-S-трансфераза, як і GPx, потребує наявності глутатіону, оскільки бере участь у реакції детоксикації ксенобіотиків, каталізуючи реакцію кон'югації електрофрільних субстратів 3 відновленим глутатіоном, таким чином, захищаючи клітину від окиснювального стресу [22]. Зниження активності GPx і GST у крові при експериментальній нефропатії ми пов'язуємо 3 можливим зменшенням вмісту глутатіону в крові та накопиченням АФО.

Також відзначали зміни вмісту вільних $\mathrm{SH}-г р у п ~ т а \mathrm{H}_{2} \mathrm{~S}$ плазмі крові щурів з експериментальною нефропатією. Спостерігали зниження вмісту SH-груп на 26,6 \% на 3-й день та на 9,3 \% на 7-й день експерименту порівняно з контрольною групою тварин. Вміст $\mathrm{H}_{2} \mathrm{~S}$ зменшувався на 28,2 та 24,3 \% на 3-й і 7-й дні відповідно порівняно 3 контрольною групою щурів.
Відомо, що SH-вмісні сполуки, до яких належать глутатіон, цистеїн, метіонін, виконують фрункцію акцепторів ОН•, знижуючи цитотоксичну та деструктивну дію АФО, цим самим відіграючи суттєву роль у підтриманні редокс-потенціалу клітин крові. Розташовані на поверхні протеїнової молекули SH-групи здатні інактивувати АФО, окиснюючись до дисульфрідів, таким чином, захищаючи внутрішні ділянки протеїнів від ушкоджень. Зниження вмісту $\mathrm{SH}-г р у п ~ т а ~ \mathrm{H}_{2} \mathrm{~S}$ у плазмі крові щурів може бути пов'язане як 3 посиленою інтенсифрікацією вільнорадикальних процесів, так і з посиленим використанням цих сполук [23].

При експериментальній нефропатії вміст церулоплазміну в плазмі крові щурів зростав на 40,9 \% на 3-й день та на 74,0 \% на 7-й день експерименту порівняно з контрольною групою тварин.

Одночасне зниження всіх показників ензимної ланки антиоксидантного захисту свідчить про виснаження антиоксидантної системи та спричиняє порушення рівноваги між виробленням вільних радикалів та системою антиоксидантного захисту. Дисбаланс між системами, що генерують АФО, та системами, які знешкоджують їх, призводить до окиснювальної модифрікації протеїнів, ліпідів і ДНК та запускає шляхи загибелі клітин [24].

При введенні мелатоніну активність каталази у крові тварин підвищувалася на 3-й день експерименту на 17,6 \% порівняно 3 групою щурів із нефропатією. На 7-й день вона зростала на 13,9 \% порівняно з групою щурів із нефропатією, але все ще достовірно відрізнялася від показників контрольної групи тварин. Активність GPхзбільшувалася на 3-йта 7-й дні експерименту на 103,5 і 99,6 \% відповідно порівняно з показниками щурів із нефропатією, але на 7-й день усе ще достовірно відрізнялася від значень контрольної групи тварин. Активність GST підвищувалася на 7-й день на 12,2 \% порівняно 3 показниками щурів із нефрропатією.

Введення мелатоніну знижувало вміст сироваткового церулоплазміну як на 3-й (на 14,8 \%), так і на 7 дні (на 34,3 \%) порівняно 3 групою щурів із нефропатією.

Церулоплазмін - Cu-вмісна фероксидаза, що бере участь в окисненні $\mathrm{Fe}^{2+}$ до його нетоксичної фрорми $\mathrm{Fe}^{3+}$. Відповідно, метаболізм заліза повинен чітко регулюватися протеїнами, що здатні транспортувати, секвеструвати та мобілізувати залізо із запасів. Саме через свою функцію церулоплазмін вважають досить ефективним антиоксидантом, що здатен попереджувати окиснювальне ушкодження ліпідів, ДНК та протеїнів [25]. 
Мелатонін підвищував рівень вільних SH-груп на 26,7 \% на 3-й день корекції порівняно з показниками експериментальних тварин, і він досягав значень контрольної групи щурів. Концентрація $\mathrm{H}_{2} \mathrm{~S}$ при введенні мелатоніну зростала на 26,7 \% на 3-й день та на 13,9 \% на 7-й день, але все ще залишалася нижчою порівняно 3 показниками контрольної групи тварин.

У нашому дослідженні введення мелатоніну сприяло зниженню процесів вільнорадикального окиснення та підвищувало антиоксидантний потенціал організму. Захисну дію мелатонін проявляє, імовірно, завдяки беспосередній його участі в нейтралізації вільних радикалів та посиленні експресії генів антиоксидантних ензимів [26].

Пряма антиоксидантна дія мелатоніну пов'язана з його будовою. У своїй структурі він містить ароматичне індольне кільце, багате на електрони, що робить його потужним донором електронів та приводить до значного зниження окиснювального стресу. Однак здатність мелатоніну зменшувати окиснювальний стрес іноді також залежить від його взаємодії з мембранними рецепторами мелатоніну, які локалізовані на клітинній мембрані або внутрішньоклітинних органелах. Ця рецепторно-опосередкована дія мелатоніну, ймовірно, полягає в стимуляції антиоксидантних ензимів. Коли мелатонін діє через рецептори, то може досягати антиоксидантного ефекту при більш низьких концентраціях, ніж ті, які потрібні, коли він діє як прямий поглинач вільних радикалів [27].

\section{СПИСОК ЛІТЕРАТУРИ}

1. Hong Y. A. Catalytic antioxidants in the kidney / Y. A. Hong, C. W. Park // Antioxidants. -2021. - No. 10. $130 \mathrm{p}$.

2. Irazabal M. V. Reactive oxygen species and redox signaling in chronic kidney disease / M. V. Irazabal, V. E. Torres // Cells. - 2020. - No. 9 (6). - P. 1342.

3. Red blood cell function and dysfunction: Redox regulation, nitric oxide metabolism, anemiaegulation, nitric oxide metabolism, anemia / V. Kuhn, L. Diederich, T. C. Stevenson Keller IV [et al.] // Antioxidants \& Redox Signaling. - 2017. - No. 13. - P. 718-742.

4. Mohanty J. G. Red blood cell oxidative stress impairs oxygen delivery and induces red blood cell aging / J. G. Mohanty, E. Nagababu, J. M. Rifkind // Front. Physiol. - 2014. - No. 5. - P. 84.

5 . The biologic effect of hydrogen sulfide and its function in various diseases / Q. Xiao, J. Ying L. Xiang, C. Zhang // Medicine (Baltimore). - 2018. - No. 97 (44)

6. Corsello T. Role of hydrogen sulfide in NRF2- and sirtuin-dependent maintenance of cellular redox balance / T. Corsello, N. Komaravelli, A. Casola // Antioxidants. 2018. - No. 7 (10). - P. 129.
Окрім того, позитивний вплив мелатоніну на стан оксидантної системи може бути зумовлений тим, що він має здатність підвищувати рівень $\mathrm{H}_{2} \mathrm{~S}$ у крові. Відомо, що $\mathrm{H}_{2} \mathrm{~S}$ збільшує рівень внутрішньоклітинного глутатіону [6], а це сприяє зростанню активності GPX та GST, які використовують відновлений глутатіон i, таким чином, підвищують спроможність антиоксидантної системи захисту.

ВИСНОВКИ. Моделювання несропатії призводить до порушення фрільтраційної здатності нирок, виникнення окиснювального стресу i порушення в системі антиоксидантного захисту, що характеризується підвищенням вмісту ТБК-активних продуктів, карбонільних похідних окисномодифрікованих протеїнів, церулоплазміну та зниженням активності каталази, супероксиддисмутази, ензимів глутатіонової системи, вмісту $\mathrm{SH}$-груп і $\mathrm{H}_{2} \mathrm{~S}$. Введення мелатоніну впродовж 7 днів сприяє нормалізації показників, що характеризують фрункціональний стан нирок, оксидантний стан організму та мають позитивний вплив на активність каталази, глутатіонпероксидази і глутатіон-S-транссрерази, вміст церулоплазміну, $\mathrm{SH}-г р у п ~ т а ~ \mathrm{H}_{2} \mathrm{~S}$.

Перспективи подальших досліджень. Доцільно дослідити механізми впливу мелатоніну на оксидантний стан і фрункціонування в різних структурах нирок антиоксидантного захисту для з'ясування можливих його механізмів дії при несрропатії.

7. Melatonin is a potential therapeutic molecule for oxidative stress induced red blood cell (RBC) injury: A review / A. Banerjee, A. Chattopadhyay, P. Pal, D. Bandyopadhyay // Melatonin Research. - 2020. No. 3. - P. 1-31.

8. Folic acid induces acute renal failure (ARF) by enhancing renal prooxidant state / A. Gupta, V. Puri, R. Sharma, S. Puri // Experimental and Toxicologic Pathology. - 2012. - No. 64 (3). - P. 225-232.

9. Назаренко О. А. Креатинін та методи його визначення / О. А. Назаренко, Т. А. Сергеєва, О. П. Солдаткін // Біотехнологія. - 2009. - № 2. - С. 107-116.

10. Камышников В. С. Справочник по клиникобиохимической лабораторной диагностике /В.С.Камышников. - Минск : Беларусь, 2000. - 463 с.

11. Мещишен І. Ф. Метод визначення окисномодиорікованих білків плазми (сироватки) крові / І. Ф. Мещишен // Буковин. мед. вісн. - 1998. - № 2 (1). C. $156-158$.

12. Колб В. Г. Справочник по клинической химии / В. Г. Колб, В. С. Камышников. - Минск : Беларусь, 1982. -290 C. 
13. Мещишен І. Ф. Метод кількісного визначення HS-груп у крові / І. Ф. Мещишен, Н.П.Григор'єва // Буковин. мед. вісн. - 2002. - № 6. - С. 190-192.

14. Dombkowski R. A. Hydrogen sulfide as an endogenous regulator of vascular smooth muscle tone in trout / R. A. Dombkowski, M. J. Russell, K. R. Olson // Am. J. Physiol. Regul. Integr. Comp. Physiol. - 2004. No. 286. - P. 678-685.

15. Чумаков В. Н. Количественный метод определения $\mathrm{Cu}, \mathrm{Zn}-$ зависимой супероксиддисмутазы в биологическом материале /В. Н. Чумаков, Л. Ф. Осинская // Вопросы мед. химии. - 1977. - № 23. - С. 712716.

16. Метод определения активности каталазы / К. А. Королюк, Л. И. Иванова, И. Г. Майорова, В. Е. Токарев // Лаб. дело. - 1988. - № 1. - С. 16-19.

17. Власова С. Н. Активность глутатионзависимых энзимов эритроцитов при хронических заболеваниях печени у детей / С. Н. Власова, Е. И. Шабулина, И. А. Перелегина// Лаб. дело. - 1990. - № 8. - С. 19-22.

18. Геруш І. В. Стан глутатіонової системи крові за умов експериментального виразкового ураження гастродуоденальної зони та дії настойки ехінацеї пурпурової / I. В. Геруш, І. Ф. Мещишен // Вісн. проблем біології та медицини. - 1998. - № 7. - С. 10-15.

19. Habig, W. H. The identity of glutathione S-transferase B with ligandin, a major binding protein of liver I W. H. Habig, M. J. Pabs, G. Fleischner // Proceedings of the National Academy of Sci. - 1974. - No. 71 (10). P. 3879-3882.

20. Interplay between ROS and antioxidants during ischemia-reperfusion injuries in cardiac and skeletal muscle / T. Zhou, E. R. Prather, D. E. Garrison, L. Zuo // Int. J. Mol. Sci. - 2018. - No. 19 (2). - P. 417.

21. Role of catalase in oxidative stress- and ageassociated degenerative diseases / N. Ankita, Y. LiangJun, J. Chandan Kumar, D. Nilanjana // Oxidative Medicine and Cellular Longevity. - 2019. - 130 p.

22. Kaur M. Oxidative stress response in liver, kidney and gills of ctenopharyngodon idellus(cuvier \& valenciennes) exposed to chlorpyrifos / M. Kaur, R. Jindal // MOJ Biol. Med. - 2017. - No. 1 (4). - P.103-112.

23. Лугініч М. М. Вплив введення мелатоніну на стан глутатіонової системи і рівень гідроген сульсріду у крові щурів при алоксановому цукровому діабеті / М. М. Лугініч, І. В. Геруш // Укр. біофармац. журн. 2019. - № 3 (60). - C. 51-56.

24. Mitochondrial electron transport chain, ROS generation and uncoupling (Review) / R. Zhao, S. Jiang, L. Zhang, Z. Yu // Int. J. Mol. Med. - 2019. - No. 44. P. 3-15.

25. Melatonin maintains the function of the blood redox system at combined ethanol-induced toxicity and subclinical inflammation in mice / N. Kurhaluk, $\mathrm{H}$. Tkachenko, O. Lukash [et al.]. - Sleep Breath. - 2020.

26. Зинчук В. В. Участие мелатонина в регуляции кислородтранспортной функции крови при окислительном стрессе, вызванном введением липополисахарида / В. В. Зинчук, М. Э. Фираго // Биомед. химия. - 2017. - № 63 (6). - С. 520-526.

27. Mitochondria: Central organelles for melatonin's antioxidant and anti-aging actions / R. J. Reiter, D. X. Tan, S. Rosales-Corral [et al.] // Molecules. - 2018. - No. 23. P. 509.

\section{REFERENCES}

1. Hong, Y.A., \& Park, C.W. (2021). Catalytic antioxidants in the Kidney. Antioxidants (Basel), 10 (1), 130.

2. Irazabal, M. \& Torres, V. (2020). Reactive oxygen species and redox signaling in chronic kidney disease. Cells, 9 (6), 1342.

3. Kuhn, V., Diederich, L., Stevenson Keller IV, T.C., Kramer, C.M., Lückstädt, W., Panknin, Ch., ... CorteseKrott, M.M. (2017). Red blood cell function and dysfunction: Redox regulation, nitric oxide metabolism, anemiaegulation, nitric oxide metabolism, anemia. Antioxidants \& Redox Signaling, 718-742.

4. Mohanty, J., Nagababu, E., \& Rifkind, J. (2014). Red blood cell oxidative stress impairs oxygen delivery and induces red blood cell aging. Frontiers in Physiology, 5, 84.

5. Xiao, Q., Ying, J., Xiang, L., \& Zhang, C. (2018). The biologic effect of hydrogen sulfide and its function in various diseases. Medicine, 97 (44), e13065.

6. Corsello, T., Komaravelli, N., \& Casola, A., (2018). Role of hydrogen sulfide in NRF2- and sirtuin-dependent maintenance of cellular redox balance. Antioxidants, 7 (10), 129.

7. Banerjee, A., Chattopadhyay, A., Pal, P. \& Bandyopadhyay, D. (2020). Melatonin is a potential therapeutic molecule for oxidative stress induced red blood cell (RBC) injury: A review. Melatonin Research, 3, 1-31.

8. Gupta, A., Puri, V., Sharma, R. \& Puri, S. (2012). Folic acid induces acute renal failure (ARF) by enhancing renal prooxidant state. Experimental and Toxicologic Pathology, 64 (3), 225-232.
9. Nazarenko, O.A., Serheieva, T.A., \& Soldatkin, O.P. (2009). Kreatynin ta metody yoho vyznachennia [Creatinine and methods for its determination]. Biotekhnolohiia - Biotechnology, 2, 107-116 [in Ukrainian].

10. Kamyshnikov, V.S. (2000). Spravochnik po kliniko-biohimicheskoy laboratornoy diagnostike (2-e izd.) [Handbook of clinical and biochemical laboratory diagnostics (2 ed.)]. Minsk [in Russian].

11. Meshchishen, I.F. (1998) Metod vyznachennia okysno-modyfikovanykh bilkiv plazmy (syrovatky) krovi [Method of determination of oxidative modifiers of plasma proteins (serum)]. Bukovynskyi medychnyi visnyk - Bukovyna Medical Bulletin, 2 (1), 156-158 [in Ukrainian].

12. Kolb, V.G., \& Kamyshnikov, V.S. (1982). Spravochnik po klinicheskoy khimii [Reference book on Clinical Chemistry]. Minsk [in Russian].

13. Meshchishen, I. F., \& Grigoyeva, N.P. (2002). Metod kilkisnoho vyznachennia HS-hrup u krovi [The method of confirmation of the HS group in blood]. Bukovynskyi medychnyi visnyk - Bukovyna Medical Bulletin, 6, 190-192 [in Ukrainian].

14. Dombkowski, R.A., Russell, M.J., \& Olson, K.R. (2004). Hydrogen sulfide as an endogenous regulator of vascular smooth muscle tone in trout. American Journal of physiology. Regulatory, Integrative and Comparative Physiology, 286, 678-685.

15. Chumakov, V.N., \& Osinskaya, L.F. (1979). Kolichestvennyy metod opredeleniya Cu, Zn-zavisimoy superoksiddismutazy $v$ biologicheskom materiale $[A$ 
quantitative method for the determination of $\mathrm{Cu}, \mathrm{Zn}$-dependent superoxide dismutase in biological material]. Vopr. med. khimii - Issues of Medical Chemistry, 5, 716721 [in Russian].

16. Korolyuk, M.A., Mayorova, L., \& Tokarev, V.E. (1988). Metod opredeleniya aktivnosti katalazy [Method for determination of catalase activity]. Laboratornoe delo - Laboratory Business, 1, 16-19 [in Russian].

17. Vlasova, S.N., Shabunina, E.I., \& Perslegina, I.A. (1990). Aktivnost glutationzavisimykh enzimov eritrotsitov pri khronicheskikh zabolevaniyakh pecheni u detey [The activity of glutathione-dependent erythrocyte enzymes in children with chronic liver diseases]. Laboratornoe delo Laboratory Business, 8, 19-22 [in Russian].

18. Gerush, I. V., \& Meshchishen, I. F. (1998). Stan hlutationovoi systemy krovi za umov eksperymentalnoho vyrazkovoho urazhennia hastroduodenalnoi zony ta dii nastoiky ekhinatsei purpurovoi [The state of the glutathione blood system under the conditions of experimental ulcerative lesions of the gastroduodenal zone and the action of tincture of Echinacea purpurea]. Visnyk problem biol. ta medytsyny - Bulletin of Problems of Biology and Medicine, 7, 10-15 [in Ukrainian].

19. Habig, W.H., Pabs, M. J., \& Fleischner, G. (1974). The identity of glutathione S-transferase B with ligandin, a major binding protein of liver. Proceedings of the $\mathrm{Na}$ tional Academy of Sciences, 71 (10), 3879-3882.

20. Zhou, T., Prather, E., Garrison, D. \& Zuo, L., (2018). Interplay between ROS and antioxidants during ischemiareperfusion injuries in cardiac and skeletal muscle. International Journal of Molecular Sciences, 19 (2), 417.

21. Nandi, A., Yan, L., Jana, C. \& Das, N., (2019). Role of catalase in oxidative stress- and age-associated degenerative diseases. Oxidative Medicine and Cellular Longevity, 1-19.
22. Kaur, M., \& Jindal, R. (2017). Oxidative stress response in liver, kidney and gills of ctenopharyngodon idellus(cuvier \& valenciennes) exposed to chlorpyrifos. MOJ Biology and Medicine, 1 (4), 103-112.

23. Luhinich, N.M., \& Gerush, I.V. (2019). Vplyv vvedennia melatoninu na stan hlutationovoi systemy $\mathrm{i}$ riven hidrohen sulfidu u krovi shchuriv pry aloksanovomu tsukrovomu diabeti [Influence of melatonin introduction on the state of glutathione system and the level of hydrogen sulfide in blood of rats with alloxan induced diabetes mellitus]. Ukrainskyi biofarmatsevtychnyi zhurnal - Ukrainian Biopharmaceutical Journal, 3 (60), 51-56 [in Ukrainian].

24. Zhao, R., Jiang, S., Zhang, L., \& Yu, Z. (2019). Mitochondrial electron transport chain, ROS generation and uncoupling (Review). International Journal of Molecular Medicine, 44, 3-15.

25. Kurhaluk, N., Tkachenko, H., Lukash, O., Winklewski, P. \& Wszedybyl-Winklewska, M., (2020). Melatonin maintains the function of the blood redox system at combined ethanol-induced toxicity and subclinical inflammation in mice. Sleep and Breathing.

26. Zinchuk, V.V., \& Firago, M.E. (2017). Uchastie melatonina $\vee$ regulyatsii kislorodtransportnoy funktsii krovi pri okislitelnom stresse, vyzvannom vvedeniem lipopolisaharida [Participation of melatonin in regulation of blood oxygen-transport function in oxidative stress induced by injection of lipopolisaccaride]. Biomeditsinskaya khimiya - Biomedical Chemistry, 63 (6), 520-526 [in Russian].

27.Reiter, R.J., Tan, D.X., Rosales-Corral, S., Galano, A., Zhou, X.J. \& Xu, B. (2018). Mitochondria: Central organelles for melatonin's antioxidant and antiaging actions. Molecules, 23, 509.

И. О. Коляник, И. В. Геруш, Н. Ф. Григорьева БУКОВИНСКИЙ ГОСУДАРСТВЕННЫЙ МЕДИЦИНСКИЙ УНИВЕРСИТЕТ, ЧЕРНОВЦЫ

\section{ВЛИЯНИЕ МЕЛАТОНИНА НА СОСТОЯНИЕ ОКСИДАНТНОЙ И АНТИОКСИДАНТНОЙ СИСТЕМ И УРОВЕНЬ СУЛЬФИДА ВОДОРОДА В КРОВИ КРЫС В УСЛОВИЯХ ЭКСПЕРИМЕТАЛЬНОЙ НЕФРОПАТИИ}

\section{Резюме}

Вступление. Окислительный стресс вовлечен в патогенез различных заболеваний, включая острое и хроническое повреждение почек, и характеризуется повышением внутриклеточного уровня активных фрорм кислорода. Это играет важную роль в развитии нефропатии и является потенциальной целью для терапевтического вмешательства. В последние годы актуально также изучение роли $\mathrm{H}_{2} \mathrm{~S}$ в поддержании окислительно-восстановительного гомеостаза и влияния на активность антиоксидантной защиты. Одним из самых распространенных антиоксидантов является мелатонин. Он способен перехватывать свободные радикалы и стимулировать активность антиоксидантных энзимов. Однако остаются невыясненными механизмы его влияния на содержание $\mathrm{H}_{2} \mathrm{~S}$ и антиоксидантную систему крови при несропатии.

Цель исследования - выяснить влияние мелатонина на состояние биохимических показателей, оксидантной и антиоксидантной систем и уровень сульфида водорода в крови крыс в условиях экспериментальной нефропатии.

Методы исследования. Эксперимент проведен на 127 нелинейных крысах-самцах массой 0,16-0,18 к2. Экспериментальную нефропатию моделировали путем одноразового внутрибрюшного введения фролиевой кислоты в дозе 250 мг/кг массы тела. Мелатонин вводили интрагастрально в течение 3 и 7 дней 
после моделирования нефропатии в дозе 10 мг/ка. В плазме крови определяли содержание мочевины, креатинина, ТБК-активных продуктов, карбонильных производных протеинов нейтрального (ОМП з7о) и лужного $\left(\mathrm{OM}_{430}\right)$ характера, церулоплазмина, $\mathrm{SH}$-групп и $\mathrm{H}_{2} \mathrm{~S}$, в гемолизате эритроцитов - активность каталазы, супероксиддисмутазы (SOD), глутатионпероксидазы (GPX) и глутатион-S-трансферазы (GST).

Результаты и обсуждение. В условиях нефропатии в крови крыс наблюдали повышение концентрации мочевины, креатинина, содержания ТБК-активных продуктов, ОМБ ${ }_{370}$, ОМБ $_{430}$, черулоплазмина и снижение активности антиоксидантных энзимов, таких, как каталаза, SOD, GPx, GST, а также содержания $\mathrm{SH}$-групп и $\mathrm{H}_{2} \mathrm{~S}$. Эти изменения свидетельствовали о нарушении фрункционального состояния почек, развитии окислительного стресса и истощении антиоксидантной защиты. Введение мелатонина в течение 7 дней способствовало нормализации показателей, которые характеризовали фрункциональное состояние почек, оксидантное состояние крови, и оказывало положительное влияние на активность каталазы, GPx, GST, уровень церулоплазмина, содержание SH-групп и $\mathrm{H}_{2} \mathrm{~S}$.

Вывод. Введение экзогенного мелатонина в дозе 10 мг/кг в течение 3 и 7 дней снижает проявления нефротического синдрома и свободнорадикального окисления биомолекул, а также оказывает нормализующее влияние на антиоксидантную систему и содержание $\mathrm{H}_{2} \mathrm{~S}$, что, вероятно, обусловлено его способностью нейтрализовать свободные радикалы и активировать антиоксидантные энзимы.

КЛЮЧЕВЫЕ СЛОВА: нефропатия; фолиевая кислота; антиоксидантная система; мелатонин; сульфид водорода.

I. O. Kolianyk, I. V. Gerush, N. P. Grygorieva

BUKOVYNA STATE MEDICAL UNIVERSITY, CHERNIVTSI

\title{
MELATONIN EFFECT ON THE STATE OF OXIDANT AND ANTIOXIDANT SYSTEMS AND HYDROGEN SULFIDE LEVEL IN THE BLOOD OF RATS UNDER CONDITIONS OF EXPERIMENTAL NEPHROPATHY
}

\begin{abstract}
Summary
Introduction. Oxidative stress is involved into pathogenesis of various diseases including acute and chronic kidney damage and is characterized by an increased intracellular level of oxygen active forms. It plays an important role in the development of nephropathy and is a potential target for therapeutic intervention. In recent years, the study of $\mathrm{H}_{2} \mathrm{~S}$ role in maintenance of oxidation-reduction (redox) homeostasis and its effect on the activity of antioxidant protection has become relevant. Melatonin is one of the most common antioxidants. It is able to bind free radicals and stimulate the activity of antioxidant enzymes. Though, the mechanisms of its effect on $\mathrm{H}_{2} \mathrm{~S}$ content and antioxidant system of blood with nephropathy remain uncertain.

The aim of the study - to find out melatonin effect on blood biochemical values, the oxidative-antioxidative system and hydrogen sulfide level in the blood of rats under conditions of experimental nephropathy.

Research Methods. The experiment was conducted on 127 non-linear male rats with $0.16-0.18 \mathrm{~kg}$ of the body weight. Experimental nephropathy was simulated by means of a single injection of folic acid into the peritoneum in the dose of $250 \mathrm{mg} / \mathrm{kg}$ of the body weight. Melatonin was introduced into the stomach during 3 and 7 days after nephropathy simulation in the dose of $10 \mathrm{mg} / \mathrm{kg}$. The following values were determined in the blood plasma: urea, creatinine, TBA-active products, carbonyl derivatives of the neutral (OMP370) and alkaline character (OMP430), ceruloplasmin, $\mathrm{SH}$-groups and $\mathrm{H}_{2} \mathrm{~S}$. The activity of catalase, superoxide dismutase (SOD), glutathione peroxidase (GPX) and glutathione-S-transferase (GST) was determined in the hemolysate of erythrocytes.

Results and Discussion. Under conditions of nephropathy the concentration of urea, creatinine, TBA-active products, OMP370, OMP430, ceruloplasmin increased, and the activity of such antioxidant enzymes as catalase, SOD, GPX, GST, the content of $\mathrm{SH}$-groups and $\mathrm{H}_{2} \mathrm{~S}$ decreased. These changes are indicative of functional disorders of the kidneys, development of oxidative stress and exhaustion of the antioxidant protection. Administration of melatonin during 7 days promotes normalization of the values characterizing the kidney functional state, blood oxidant state, and produces a positive effect on the activity of catalase, GPx, GST, ceruloplasmin level and the content of $\mathrm{SH}$-groups and $\mathrm{H}_{2} \mathrm{~S}$.

Conclusion. Administration of exogenous melatonin in the dose of $10 \mathrm{mg} / \mathrm{kg}$ during 3 and 7 days reduces the signs of nephrotic syndrome and free radical oxidation of biomolecules, normalizes antioxidative system and $\mathrm{H}_{2} \mathrm{~S}$ content, which might be associated with its ability to neutralize free radicals and activate antioxidant enzymes.
\end{abstract}

KEY WORDS: nephropathy; folic acid; antioxidant system; melatonin; hydrogen sulfide.

Адреса для листування: І. В. Геруш, Буковинський державний медичний університет, Театральна площа, 2, Чернівці, 58002, Україна, e-mail: gerushiv@ukr.net. 